\title{
Tax Literacy among Employees: Sabah and Sarawak's Perspective
}

\author{
Nero Madi \\ Faculty of Accountancy, Universiti Teknologi MARA Sarawak \\ Jalan Meranek 94300 Kota Samarahan, Malaysia \\ Tel: 60-82-677-681Ｅ-mail: neromadi@yahoo.com \\ Amrizah Kamaluddin \\ Faculty of Accountancy, Universiti Teknologi MARA Malaysia \\ Tingkat 11 Bangunan SAAS UiTM, 40450 Shah Alam, Malaysia \\ Tel: 60-3-5544-4941 E-mail: amrizahk@yahoo.co.uk \\ Tamoi Janggu
}

Faculty of Accountancy, Universiti Teknologi MARA Sarawak, Jalan Meranek 94300 Kota Samarahan

Tel: 60-82-677-621Ｅ-mail: tjanggu@yahoo.com

Muliati Binti Aba Ibrahim

Faculty of Accountancy, Universiti Teknologi MARA Sarawak, Jalan Meranek 94300 Kota Samarahan, Malaysia

Tel: 60-82-677-668 E-mail: muliatihai@yahoo.com.sg

Aizimah Binti Abu Samah

Academy of Language Studies, Universiti Teknologi MARA Sarawak, Jalan Meranek 94300 Kota Samarahan

Sarawak, Malaysia

Tel: 60-82-677-347Ｅ-mail: aizas@sarawak.uitm.edu.my

Kamaruzaman Jusoff (Corresponding author)

Faculty of Forestry, Universiti Putra Malaysia, Serdang 43400, Selangor. Malaysia

Tel: 60-3-8946-7176 E-mail: kjusoff@yahoo.com

This research is financed by Research and Development and Commercialization Unit (URDC) of Univesiti Teknologi MARA Sarawak Campus.

\begin{abstract}
The main intent of this paper is to gauge the level of tax literacy among taxpayers in Sabah and Sarawak. It is vital to shed light on our preparation to face the challenge posed by the implementation of Self -Assessment System (SAS) in 2004 whereby the taxpayers are expected to be functionally tax-literate in computing their own tax liabilities accurately. Methodologically, the subjects were randomly sampled from taxpayers working in a few selected towns in Sarawak and Sabah. Statistical tests like t-tests and chi-square were applied onto the means of tax literacy scores by each state and the taxpayers' respective workplaces. The taxpayers in Sarawak were found to be more tax-literate as compared to their counterparts in Sabah. Nonetheless, the taxpayers in both states were not eventually prepared for SAS. More aggressive efforts were recommended to raise the level of tax literacy among the taxpayers.
\end{abstract}

Keywords: Tax literacy, Self-Assessment System (SAS), Taxpayers

\section{Introduction}

Self-Assessment System (SAS) for taxpayers in Malaysia for 2004 began in 2005. This was a move in line with the shifting of Preceding Year Assessment (PYA) to the Current Year Assessment (CYA) proposed under budget 2000. It was to replace the Official Assessment System (OAS). The implementation of SAS was carried out in stages. It was first imposed on companies in 2001 and implemented to partnerships and individuals in 2004. It was intended to enhance efficiency by improving compliance, speeding up assessment process and facilitating collection of taxes. The important element of SAS is that the onus for computing tax liability lies with the taxpayers. A taxpayer is expected to be "functionally literate" to determine his own taxable income and income tax payable; and to furnish correct returns to Inland revenue Board (IRB) which may be a daunting task for some taxpayers. IRB, on the other hands, will conduct a 
desk audit to verify the correctness and accuracy of the taxpayers' computation. Shanmugam (2003) stated that countries which have applied SAS managed to reduce the tax administration cost and improved their efficiency.

The central issue of this paper is to gauge the general level of tax literacy among employees in public and private sectors in the event of Self-Assessment System Implementation on taxable individuals in 2004. The question posed was, "Are the individual taxpayers ready for such a change in 2005 for income earned in 2004?" The success of this new system relies on the attitudes and willingness of taxpayers to upgrade their tax knowledge (Sabri, 1993; Robert et al., 1994 and Kasipillai, 1996). Previous studies by Bardai (1992); Kasipillai and Baldry (1995) and Razman and Ariffin (2000) showed that the composition of our tax-paying society who could have been classified as literate was still unsatisfactory. Nero and Amrizah $(2003 ; 2005)$ indicated that only $13 \%$ of the taxable individuals in Sarawak can be classified as "very literate". The same study reflected that the level of awareness of taxpayers on matters relevant to SAS was very low.

Previous tax literacy studies in Malaysia were just describing the tax literacy scenario at Klang Valley and northern part of West Malaysia. This study not only extended the tax literacy to Sabah and Sarawak, but also discussed the implication of tax literacy scores in detail. This study also employs the more accurate and current research instrument in determining the tax functional literacy where literacy items were actually taken and adapted from the actual tax return form and not based on the percentage of 'Ability to fill the tax form' and 'Seeking professional help to fill the tax form' as being done by prior tax literacy studies. The contribution of this paper is not only extending the coverage of tax literacy study but also providing a more accurate tax literacy score hence useful for policy-making decisions. It is specifically focused on employment and not mixing it up with general issues on business taxation as what some prior studies did.

Tax literacy is the ability to fill in the tax form and calculate their tax liabilities independently (Bardai, 1992; Razman and Ariffin, (2000). Nero and Amrizah (2003; 2005) and Amrizah and Nero (2005) emphasize that respondents should know how to determine tax liability if they know what constitutes taxable income, deductible deductions, claimable tax reliefs and rebates. The only aspect that has not been explored in this tax literacy paper is the application of tax rate against the taxable income before claiming tax rebates to arrive at tax payable.

In Pryor and Schaffer (1997: 6), they define functional literacy as: ...the ability to use skills in reading, interpreting documents, and carrying out quantitative calculations in real-life situations...

A person can therefore be said to be functionally literate if he/she can read, write and calculate for his/her own self. The tax literacy definition is not only practical, but also meets the commonly-believed notion of literacy requirement as described above.

\section{Methods}

The data were collected via questionnaires. The population of taxable individuals was obtained from the IRB Kota Kinabalu, Sabah (Table 1) and from the various Section Heads of IRB Kuching, Sarawak. For the total population of 77, 596 in Sabah and 134, 555 in Sarawak, according to Krejcie and Morgan (1970), it is sufficient to have a sample size of 400 to 500 respondents respectively. Hence the sample size for each town (Table 1) was derived based on a pro-rata basis. To ensure that the validity and reliability of data collected were maintained, a full list of private companies and government offices was obtained from the Registrar of Companies and telephone directory (Yellow pages) respectively. The respondents were selected randomly from the list.

\section{Results and Discussions}

\subsection{Reliability analysis using Cronbach Alpha}

The Cronbach Alpha coefficients for tax literacy and awareness were quite reliable as shown in Table 2. The alpha value of understanding tax jargons and tax vehicles were also within an acceptable range.

\subsection{Literacy score}

Tax literacy, which is the central issue of the paper, was captured via Section C of the questionnaire. A total of 40 questions relevant to issues under taxation for employment were asked. One mark was awarded for a correct answer and none was given for a wrong one. The main objective of this paper is to determine the level of functional tax literacy among the employees working in public and private sectors in Sabah and Sarawak. It is disheartened to report that the overall mean score for the two states is about $60 \%$ which is within the 'literate' category (see Table 3 ). By category, about six (6) percent of the respondents were very literate whereas three-quarter of them were just literate and $18.6 \%$ were illiterate.

\subsection{Tax literacy: Sabah versus Sarawak Employees}

The hypothesis for this comparison between Sabah and Sarawak employees is: 
Ho1: There is no significant difference in the mean score of tax literacy among taxable individuals in Sabah and Sarawak.

To investigate the difference in the mean scores, an independent sample t-test was conducted. The results of the t-test are shown in Table 4. As reported in that Table 4, the taxpayers in Sarawak obtained a higher mean score as compared to their counterparts in Sabah. As such, taxpayers in Sarawak are more tax-literate. Hol is therefore rejected due to the results.

Being more tax-literate implies that their tax liability computations are more accurate in which they are able to anticipate year end tax expenses in their personal cash flows management. Tax illiteracy, on the contrary, has a few adverse implications on the taxpayers. Firstly, their own tax calculations though guided by e-filing system, may not be the correct figure as there could be some unclaimed tax reliefs and rebates or income have been unreported. Under SAS, the unclaimed tax reliefs and rebates are self-imposed penalties for not computing their tax liabilities correctly. Secondly, inaccurate tax computation means that some sources of income are unreported. This will attract tax desk audits and can therefore be subjected to additional assessment. Thirdly, a penalty will be imposed on any late payment of tax. Such financial burdens are avoidable if they have known some avenues for updating their own tax knowledge. Goody (1996; 1997) as cited by Walter (1997) states that functional literacy has a profound economic impact on individuals. Another researcher agreed that functional literacy did help a person to escape from the prison of ignorance (Fraze, 1996) and this ignorance cannot be defended in court of law while Stokes (1993) further elaborated that functional literacy in business would have a competitive advantage over their competitors. High tax literacy rate is commendable because if appropriately exploited, it can actually enhance and improve compliance by allowing taxpayers to legally and commercially plan every transaction in order to avoid paying more tax. Tax literacy is crucial in order to tap on tax loopholes in reducing tax obligation which is legal in nature. This will obviously help to keep taxpayers being informed about SAS development.

\subsection{Independent $t$-test on tax awareness by state}

Independent sample t-test was applied to gauge whether or not, there was a significant means of value difference of taxpayers' level of tax awareness. The results indicated that there were strong significant differences in the means value of some variables, as revealed in Table 5.

The results show that taxable individuals in Sarawak are confirmed to be more knowledgeable in tax matters pertaining to personal taxation within the context of Malaysian income tax laws in which the findings are actually good for taxpayers as they would be more aware of tax administration. They are not ignorant to the penalties imposed for not reporting all income and providing incorrect information to the tax authority. Nevertheless, this awareness does not eventually guarantee a total of compliance as argued in Mottiakavandar et al (2003) when they asserted that it was the taxpayer's perception towards the fairness of the tax system that influenced one' tax compliance and not tax knowledge as previously claimed by Sabri (1993), Robert et al. (1996) and Kasipillai (1996). The finding from Mottiakavandar et al (2003) was also supported by earlier study by Fallan and Eriksen (1996).

\subsection{Utilization of tax vehicles}

The data for this section was captured via Section D of the questionnaire. In this section, the respondents were required to indicate whether or not they have applied the identified tax vehicles or avenues in enhancing their tax knowledge. The respondents were also required to indicate the level of effectiveness of the tax vehicles used. The most popular method used by taxpayers in updating themselves with tax information was reading tax pamphlets and other printed tax materials. About $68 \%$ of the respondents utilized this avenue. The next popular tax vehicle was a commentary on our national budgets followed by TV talks which accounted for $56.3 \%$ and $50.3 \%$ utilization rate respectively. The tax vehicles which were not widely used were: taxpayers' service week, TPSW (49\%), press release (49\%), tax seminar/workshop (30.3\%), radio talks (35.2\%) and the least popular was IRB's webpage (28.8\%). Tax avenues utilization by state revealed that taxpayers in Sarawak outperformed their counterparts in Sabah for majority of the avenues. This observation is presented in Figure 1.

The chi-square analysis of respondents' tax vehicles utilization revealed that those who found to be tax literate and very literate were mostly respondents utilizing budget commentaries and pamphlets and printed tax materials. $60 \%$ (391 out of 651) respondents of 'literate' and 70\% (38 of 54) respondents of 'very literate' categories from Sabah and Sarawak clearly explained this finding. They read the budget commentary to improve their tax knowledge (Table 6). In addition to this observation, there is a strong association between these variables which indicates that tax literacy is dependent on the reading of budget commentaries made by interested parties such as professionals and local politicians.

Table 7 depicts literacy category by pamphlets and printed materials. It could be observed that about $68.6 \%$ (593 of 865 ) respondents of Sabah and Sarawak utilized pamphlets and printed materials. Majority of 593 respondents who made use of this tax vehicle were literate and very literate. Those using this avenue accounted for more than double of those who did not use this vehicle which were categorized as literate and very literate. Only $22.7 \%$ of those who did not make use 
of this avenue were literate and very literate as compared to $58.6 \%$ of those utilizing this avenue in acquiring the necessary tax knowledge.

Further analysis using One-Way ANOVA on tax vehicles used by the respondents indicated that there were significant differences in the mean scores with respect to those who utilized vehicles such as tax seminars, press release, commentaries on national budget and pamphlets, and other printed tax materials, as compared to their counterparts who did not use such avenues to update themselves with tax information. The results are reported in Table 8 .

IRB, to some extent, has satisfactorily educated the taxpayers on basic rules and regulation of tax administration, specifically the responsibilities of taxpayers and offences and penalties of tax violations. Providing information using pamphlets and printed tax materials can be enhanced as this approach is positively identified to be related to tax literacy. The taxing authority, however, cannot assume every taxpayer is informed about tax matters by having published the tax information over the IRB's webpage. Taxpayers at different places of work might require different approaches in updating their tax knowledge. The access to the IRB's webpage is very much hindered by poor internet access and network coverage. This could be the main reason why the utilization rate for webpage is very low (28.8\%). The IRB webpage is comprehensive but not quite practical at the moment as our network coverage and internet infrastructure are still not properly sufficient and conducive.

\section{Conclusion}

As noted earlier in the introductory paragraph, the main objective of the paper is to determine the level of tax literacy in Sabah and Sarawak. Based on the overall mean score, it can thus be concluded that the tax literacy level in the two states is not quite satisfactory. Judging from the literacy scores reported, it can be generalized that majority of taxpayers in East Malaysia are barely literate. This means that income earners have an average understanding of basic tax knowledge. Hence their computation of tax liabilities might not be accurate. They may require assistance in determining the correct amount of tax to be paid. The taxpayers in Sarawak are eventually more tax-literate as compared to their counterparts in Sabah as indicated by significantly higher tax literacy mean score. It is also concluded that higher tax literacy score is attributed to a wider and greater utilization of tax vehicles by way of reading tax pamphlets and printed tax materials. The contribution of this paper is that the overall literacy rate using percentage of correct responses is more accurate as it detailed out the respondents into their functional literacy categories: illiterate, literate and very literate based on the scores obtained. This research is therefore unique in its contribution as compared to prior studies where tax literacy levels were determined based on percentage of 'ability to fill tax form' and 'seeking professional help to fill the tax form' instead of functional literacy scores described above.

To address the issues related to tax literacy among taxpayers in East Malaysia, several recommendations are suggested in this paper. Firstly, more aggressive approaches should be adopted to educate taxpayers. Taxation knowledge can be taught at upper secondary school level to inculcate tax responsibilities among potential revenue contributors. Secondly, awareness of Self Assessment System (SAS) requires tax education in the form of providing brochures and tax updates which can be distributed to taxable employees through their employers or sent to their residential addresses. For future research, it would further provide useful insight if another study can be conducted to probe the actual level of functional tax literacy of taxpayers by conducting pre- and post-workshop and seminar on personal tax liability computation.

\section{References}

Amrizah K. and Nero M. (2005). Tax literacy and Tax awareness of Salaried Individuals in Sabah and Sarawak, National Accounting Research Journal Vol. 5 No. 1/2005: 71-89.

Bardai, B. (1992). Tax Illiteracy in Malaysia: Problems Solutions, Journal of ACCAMADIA II (2): 7-31.

Eriksen, K. and Fallan, L. (1996). Tax knowledge and Attitudes toward Taxation: A report on a Quasi Experiment, Journal of Economic Psychology, 17(3): 387-402.

Fraze, V. (1996). Workers Learn to Walk so They can run, Personnel Journal, May: 115-120.

Kasipillai, J. \& Baldry, J. (1995). What do Malaysian Taxpayers know ?, Malaysian Accountant, February: 2-7.

Kasipillai, J. (1996). Taxpayer's Understanding and Knowledge Index (TUKI) as a Clue to Non-Compliance, Unpublished Ph.D. Thesis, Australia.

Krejcie, R. and Morgan, D. (1970). Educational and Psycological Measurement 30: 607-610.

Mottiakavandar, R., Ramayah, T. Haron, H. and Jili A. (2003). Factors influencing Compliance Behaviour of Small Business Entrepreneurs, Tax Nasional, $1^{\text {st }}$ Quarter: 20-26.

Nero M. and Amrizah K. (2003), Are Salaried Individuals in Sarawak ready for Self-Assessment System, SAS, in 2004?, paper presented at SEMACC 2003, December 2003, Putra Palace, Perlis.

Nero M. and Amrizah K. (2005). Tax Literacy among Employees in Sarawak, Jurnal Akademik December 2005 Issue pp. 22-42. 
Pryor, F. and Schaffer, D (1997). Wages and university educated: A Paradox Resolved, Monthly Labour Review, Vol 120 No. 7 pp3-14.

Razman, A. A. L . and Ariffin A. N. 2000, 'Tax Literacy among Taxpayers in Klang Valley' paper presented at Seminar FEP 2000, Review Beach Resort, Pulau Pinang, October 2000 20-23.

Roberts, L.H., Hite, P.A. and Bradley, C. F. (1994). Understanding Attitudes Towards Progressive Taxation. Public Opinion Quarterly 58: 165-190.

Sabri, S. (1993). Tax Ethics and Taxpayers Attitudes, Masters Thesis, Kuala Lumpur: University of Malaya.
Self
Assessment
System
[Online].
Available:
http://www.hasilnet.org.my./web..

68C5F5D8FF849313482569520025CB6D? Retrieved on August 7, 2003

Shanmugam, S. (2003). Managing Self Assessment - An Appraisal, Tax Nasional $1^{\text {st }}$ Quarter : 30-31.

Stokes, S.L (1993). Blueprint for Business Literacy, Information System Management, 10 (2):73-76.

Walter, S.L (1997), Conceptualization of Literacy Anline]. Available: http://gama.sil.org/lingualink/library/literacy/Krz313/Krz221/Krz230.htm Retrieved on Nov. 18, 1998)

Table 1. Population and sample size of respondents

\begin{tabular}{|c|c|c|}
\hline City / Town & Population & Sample Size \\
\hline Kota Kinabalu & $51,569^{*}$ & 243 \\
\hline Sandakan & $12,428^{*}$ & 102 \\
\hline Tawau & $13,599^{*}$ & 84 \\
\hline Sub-total & $\underline{77,596}$ & $\underline{429}$ \\
\hline Kuching & $45,000^{*}$ & 181 \\
\hline Sibu & $40,000^{*}$ & 134 \\
\hline Bintulu & $16,741^{*}$ & 59 \\
\hline Miri & $32,815^{*}$ & 155 \\
\hline Sub-total & $134,555^{*}$ & $\underline{\underline{535}}$ \\
\hline
\end{tabular}

*Source: Section Heads in Inland Revenue Board

Table 2. Cronbach Alpha for literacy variables

\begin{tabular}{|l|c|c|}
\hline Variables & No of Items & Cronbach Alpha \\
\hline Tax literacy items & 34 & 0.809 \\
\hline Tax awareness & 12 & 0.872 \\
\hline Utilization of tax vehicles & 8 & 0.698 \\
\hline
\end{tabular}

Table 3. Tax literacy description

\begin{tabular}{|l|l|l|}
\hline Category & Scores & Description \\
\hline Illiterate & $24-49 \%$ & $\begin{array}{l}\text { Taxpayer with very poor skills, unable to understand tax terminologies used in } \\
\text { the tax form. }\end{array}$ \\
\hline Literate & $50-74 \%$ & $\begin{array}{l}\text { Having average understanding of the basic tax knowledge. However, they } \\
\text { require assistance in determining tax liability. }\end{array}$ \\
\hline Very literate & $75-100 \%$ & $\begin{array}{l}\text { Very much aware of tax issues. Possess high understanding of tax term and } \\
\text { should be able to determine their own tax liabilities. }\end{array}$ \\
\hline
\end{tabular}

(Adopted from Nero and Amrizah, 2003)

Table 4. Tax literacy by state

\begin{tabular}{|l|c|c|c|c|c|c|}
\hline \multirow{2}{*}{ Literacy item } & State & $\mathrm{N}$ & $\begin{array}{c}\text { Mean } \\
\text { scores }\end{array}$ & Std. Dev & F-value \\
\hline \multirow{2}{*}{ Literacy score } & Sabah & 429 & 59.23 & 13.63 & 6.11 \\
\cline { 2 - 6 } & Sarawak & 539 & 61.06 & 12.54 & 0.014 \\
\hline
\end{tabular}

* significant at the 0.05 level 
Table 5. Independent t-test on tax awareness by state

\begin{tabular}{|l|l|l|l|l|l|}
\hline Variables & State & N & Mean & Std Dev. & Sig. (2-tailed) \\
\hline Informing new address & Sabah & 424 & 2.61 & 0.646 & $0.009^{*}$ \\
& Sarawak & 534 & 2.72 & 0.563 & \\
\hline Penalty not reporting all income & Sabah & 424 & 2.5 & 0.660 & $0.004^{*}$ \\
& Sarawak & 537 & 2.62 & 0.644 & \\
\hline Penalty for incorrect information & Sabah & 423 & 2.54 & 0.658 & $0.004^{*}$ \\
& Sarawak & 537 & 2.66 & 0.602 & \\
\hline Tax rate based on residence status & Sabah & 423 & 1.85 & 0.783 & $0.042^{*}$ \\
& Sarawak & 536 & 1.95 & 0.778 & \\
\hline
\end{tabular}

*significant at 0.05 (equal variance assumed)

Table 6. Literacy category by budget commentary

\begin{tabular}{|l|c|c|c|c|c|c|}
\hline \multirow{2}{*}{$\begin{array}{l}\text { Literacy } \\
\text { Category }\end{array}$} & \multicolumn{2}{|c|}{\begin{tabular}{c}
\multicolumn{2}{c|}{ Read not read } \\
Budget Commentaries
\end{tabular}} & \multicolumn{2}{c|}{ Budget Commentaries } & \multicolumn{2}{c|}{ Total } \\
\cline { 2 - 7 } & No. & $\%$ & No. & $\%$ & No. & $\%$ \\
\hline Illiterate & 102 & 11.8 & 59 & 6.8 & 161 & 18.6 \\
\hline Literate & 260 & 30.0 & 391 & 45.2 & 651 & 75.2 \\
\hline Very Literate & 16 & 1.8 & 38 & 4.4 & 54 & 6.2 \\
\hline & 378 & 43.6 & 488 & 56.4 & 866 & 100.0 \\
\hline
\end{tabular}

Chi-Square value $=33.375$; Asymp. Sig. $=0.000$

Table 7. Literacy category by pamphlets and printed materials

\begin{tabular}{|l|c|c|c|c|c|c|}
\hline \multirow{2}{*}{$\begin{array}{l}\text { Literacy } \\
\text { Category }\end{array}$} & \multicolumn{2}{|c|}{$\begin{array}{c}\text { Did not read } \\
\text { Pamphlet and printed materials }\end{array}$} & \multicolumn{2}{c|}{$\begin{array}{c}\text { Read Pamphlet and printed } \\
\text { materials }\end{array}$} & \multicolumn{2}{c|}{ Total } \\
\cline { 2 - 7 } & No. & $\%$ & No. & $\%$ & No. & $\%$ \\
\hline Illiterate & 75 & 8.7 & 86 & 9.9 & 161 & 18.6 \\
\hline Literate & 182 & 21.0 & 468 & 54.1 & 650 & 75.1 \\
\hline Very Literate & 15 & 1.7 & 39 & 4.5 & 54 & 6.2 \\
\hline & 272 & 31.4 & 593 & 68.6 & 865 & 100.0 \\
\hline
\end{tabular}

Chi-Square value $=21.032 ;$ Asymp. Sig. $=0.000$

Table 8. Respondents' mean scores by utilization of tax vehicles

\begin{tabular}{|l|c|c|c|c|}
\hline \multicolumn{1}{|c|}{ Tax Vehicle } & $\begin{array}{c}\text { Mean Score } \\
\text { 'Utilized Tax } \\
\text { Vehicle' }\end{array}$ & $\begin{array}{c}\text { Mean Score } \\
\text { 'Not Utilizing Tax } \\
\text { Vehicle' }\end{array}$ & F-Value & Sig. value \\
\hline Tax Seminar & 62.55 & 60.05 & 6.994 & 0.008 \\
\hline Press Release & 62.56 & 59.31 & 14.663 & 0.000 \\
\hline Budget Commentaries & 63.13 & 57.83 & 37.936 & 0.000 \\
\hline Pamphlets & 62.42 & 57.28 & 31.031 & 0.000 \\
\hline
\end{tabular}

Significant at the level of 0.05

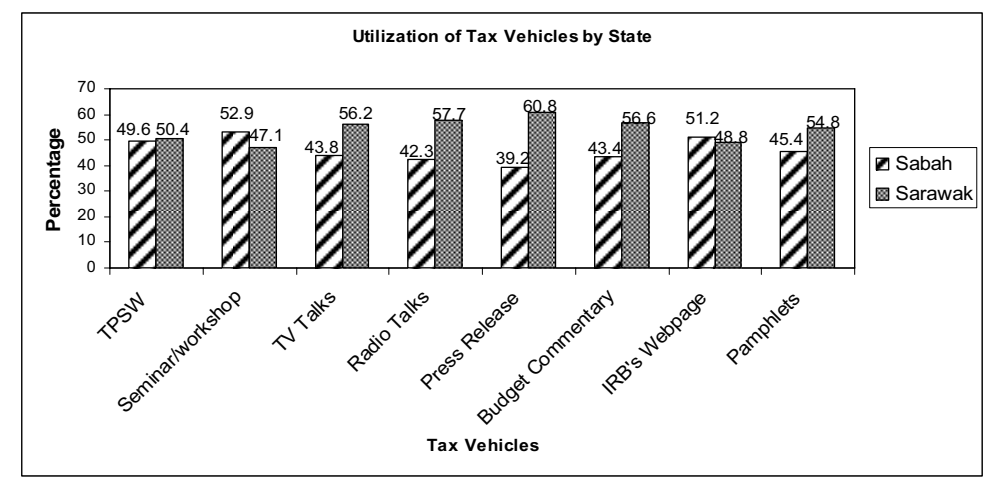

Figure 1. Utilization of tax vehicles by state 